\title{
Perinatal Respiratory Control and Its Modulation by Adenosine and Caffeine in the Rat
}

\author{
ERIC HERLENIUS, ULRIKA ÅDÉN, LIE QI TANG, AND HUGO LAGERCRANTZ \\ Department of Woman and Child Health, Karolinska Hospital [E.H., U.A., L.Q.T., H.L.], and Department \\ of Physiology and Pharmacology, Karolinska Institutet [U.A.], 17176 Stockholm, Sweden
}

\begin{abstract}
ABST
The perinatal development of respiratory rhythm generation
and its modulation by adenosinergic drugs have been examined
in rats from embryonic 18 (E18) to postnatal $\mathrm{d} 3$ using an in
vitro brain stem-spinal cord preparation. Generation of rhythmic
respiratory activity in the medulla oblongata and inhibition of
this activity by pontine structures were evident on E18. The
adenosine $\mathrm{A}_{1}$-receptor agonist, $N^{6}$ - $(2$-phenylisopropyl) adeno-
sine, $\mathrm{R}(-)$ isomer (R-PIA) $(1 \mu \mathrm{M})$, induced an age-dependent
reduction of respiratory frequency that could be reversed by the
adenosine antagonist theophylline $(55 \mu \mathrm{M})$. The effect of R-PIA
was reduced $24 \mathrm{~h}$ after birth compared with 21 and 2 h postnatal
age. In preparations from pups that had been exposed to a low
dose of caffeine ( 0.3 g/L in drinking water to dams), pontine
inhibition of respiratory rhythm generation in the medulla was
more pronounced. When the pons was removed, the respiratory
frequency was higher than in the control group. Adenosine
$\mathrm{A}_{1}$-mRNA and $\mathrm{A}_{1}$-receptor development in pons and medulla
were studied, and by E18, mRNA, receptor protein, and func-
tional coupling to G-proteins were confirmed using guanylyl-5'-
O- $\left(\gamma\right.$ - $\left[{ }^{35} \mathrm{~S}\right]$ thio)-triphosphate binding. There were no major
changes in receptor numbers or distribution of $\mathrm{A}_{1}$ receptors or
mRNA in rat pups subjected to caffeine exposure. We conclude
\end{abstract}
ABSTRACT

that respiration is already modulated by adenosine $\mathrm{A}_{1}$ receptors at the level of the medulla oblongata in the fetal period in an age-dependent manner. Furthermore, long-term maternal caffeine intake during gestation seems to increase the pontine inhibition of, and the activity of, respiratory rhythm-generating neuronal networks in medulla oblongata without detectable changes in expression of $\mathrm{A}_{1}$-receptor number or $\mathrm{A}_{1}$-receptor mRNA. (Pediatr Res 51: 4-12, 2002)
CPA, $N^{6}$-cyclopentyladenosine
CPG, Central Pattern Generator
DPCPX, 8-cyclopentyl-1,3-dipropylxanthine
$f_{\mathbf{R}}$, frequency of respiratory activity (bursts/min)
$\mathbf{T}_{\mathbf{i}}$, inspiratory time
R-PIA, $\boldsymbol{N}^{\mathbf{6}}$-(2-phenylisopropyl) adenosine, R (-) isomer
aCSF, artificial cerebrospinal fluid
E, embryonic day
$\mathbf{P}$, postnatal day
GTP $\gamma\left[{ }^{35} \mathrm{~S}\right]$, guanylyl-5'-O- $\left(\gamma-\left[{ }^{35} \mathrm{~S}\right]\right.$ thio $)$-triphosphate
$\mathrm{CV}$, coefficient of variation

\section{Abbreviations}

Fetal respiratory movements are episodic and progressively more inhibited toward the end of pregnancy when periods without respiratory movements dominate (1). Respiratory activity must be generated continuously from birth. New tactile stimuli, such as light, cooling, removal of the umbilical circulation, arousal, air in the upper and lower airways, increased pulmonary blood flow, increased oxygen consumption, vagal input from mechanoreceptors, are all involved in the initiation

Received August 28, 2000; accepted June 29, 2001.

Correspondence and reprint requests: Eric Herlenius, M.D., Ph.D., Department of Women and Child Health, Astrid Lindgren Children's Hospital Q2:07, Karolinska Institutet, 17176 Stockholm, Sweden; e-mail: Eric.Herlenius@dsg.ki.se

Supported by grants from the Swedish Medical Research Council (SMFR Nos. 5234 and 2553), the Swedish Society for Medical Research, Society for Childcare, and the Jeanssonska and the Fraenckel Foundations for Medical Research. and maintenance of breathing (2). This transition of respiratory control is probably related to modulatory factors affecting the CPG for respiration located in the brain stem (rostral ventrolateral medulla oblongata).

Adenosine is one of the neuromodulators involved in respiratory control and may be especially important around birth (3-5). Centrally applied adenosine analogs depress respiratory rate and depth $(6-8)$ via adenosine $A_{1}$ receptors in the brain stem $(5,9)$. Circulating levels of adenosine decrease immediately after birth (3), correlating to decreased extracellular levels in the brain (10), and a decrease of adenosinergic inhibition may contribute to the establishment of postnatal breathing.

Furthermore, the effect of adenosine is antagonized by caffeine in doses resembling those daily consumed by humans 
(11). High doses of caffeine intake during gestation or the early postnatal period have been shown to alter adenosine receptor development (12), affect postnatal behavior, and increase the incidence of apnea in rats $(11,13-16) . \mathrm{Po}_{2}$ during fetal life is lower than after birth. This will increase adenosine levels (17) and also the activity of pontine centers (18), both of which have been shown to depress respiratory centers in the medulla oblongata $(8,19)$. The possible roles of a decreased adenosinergic and pontine inhibition in the change of respiratory control after birth are not known.

The present study was undertaken to investigate the perinatal transition of the respiratory control and its modulation by adenosine. We were particularly interested in studying the effects of adenosine on medullary (CPG) and pontine structures involved in respiratory control. To study the effects of longterm adenosine receptor modulation (blocking), the fetuses and neonates were exposed to caffeine. This is also interesting as many human fetuses and neonates are exposed to methylxanthines in doses that may cause both short- and long-term effects on adenosine receptor expression and behavior. To compare central respiratory control before and after birth an in vitro brain stem-spinal cord preparation from fetal $(20,21)$ and neonatal rats was used. To examine a structural correlate to these functional studies of adenosine in the developing respiratory system, we also studied the ontogeny of adenosine $\mathrm{A}_{1}$ receptors and their functional coupling to G-proteins and $A_{1}$ recepter mRNA in pons and medulla.

We show in the present paper that even though the isolated respiratory $C P G$ does not undergo major changes at birth, the ability of adenosine $A_{1}$ receptors to inhibit the respiratory rhythm decreases within $24 \mathrm{~h}$ after birth. Furthermore, in pups exposed to a low dose of caffeine, the pontine inhibition of brain stem respiratory rhythm is increased.

\section{METHODS}

\section{Experimental Animals}

Timed-pregnant Wistar rats and their litters were used. Dams were given caffeine (Sigma Chemical Co., St. Louis, MO, U.S.A.; $0.3 \mathrm{~g} / \mathrm{L} ; n=23$ ) in the drinking water, exchanged every third day to fresh solutions, from E 2 throughout gestation and postnatal life. Twenty-one dams received ordinary tap water. The day when a vaginal plug was found was designated E0. The regional animal ethics committee approved the experiments, which followed the European Community regulations.

\section{Brain Stem-Spinal Cord Preparation}

The brain stem and spinal cord of E18 and E21 fetal rats and 2-h, 24-h, and 72-h (P3) postnatal Wistar rats $(n=76)$ were dissected and isolated as previously described $(5,22)$. One fetal rat from each litter was killed immediately $(<60 \mathrm{~s})$ after decapitation and cesarean section had been performed on the mother. The preparation was continuously perfused at a rate of $3.0-3.5 \mathrm{~mL} / \mathrm{min}$ in a $2-\mathrm{mL}$ chamber with the following aCSF (mM): $\mathrm{NaCl}, 124 ; \mathrm{KCl}, 5.0 ; \mathrm{KH}_{2} \mathrm{PO}_{4}, 1.2 ; \mathrm{CaCl}_{2}, 2.4 ; \mathrm{MgSO}_{4}$, 1.3; $\mathrm{NaHCO}_{3}, 26$; glucose, 30; equilibrated with $95 \% \mathrm{O}_{2}$ and $5 \% \mathrm{CO}_{2} ;$ at $27 \pm 0.5^{\circ} \mathrm{C}, \mathrm{pH}$ 7.4. Forty-four preparations were decerebrated rostral to cranial nerve $\mathrm{V}$, and recordings of respiratory activity were performed with the pons remaining during perfusion with normal aCSF. A pontomedullary transection was then performed in all preparations $(n=76)$, rostrally decerebrating the brain stem between cranial nerve root VI and the lower border of the trapezoid body.

Respiratory activity of the preparation was recorded from the $\mathrm{C} 4$ or $\mathrm{C} 5$ ventral roots (C4) using suction electrodes. In some experiments $(n=20)$ the unit activity of respiratoryrelated neurons in the ventrolateral medulla was also recorded extracellularly using a glass microelectrode filled with $2 \%$ pontamine sky blue in $0.5 \%$ sodium chloride (resistance, $2-6$ $\mathrm{M} \Omega$ ). The electrode was inserted through the ventral surface into the rostral ventrolateral medulla with a micromanipulator (MW-4, Narishige, Tokyo, Japan). Respiration-related neuronal activity was found 50-300 $\mu \mathrm{m}$ below the surface (23).

Signals were amplified and band-pass filtered $(10 \mathrm{~Hz}$ to 5 $\mathrm{kHz}$, differential AC amplifier model 1700, A-M Systems, Everett, WA, U.S.A.). The $\mathrm{C} 4$ activity was rectified and integrated with a time constant of $100 \mathrm{~ms}$. These activities were continuously monitored, registered with a strip-chart recorder, digitized continuously or in 2- to 3 -min intervals $/ 10 \mathrm{~min}$, at $1-5 \mathrm{kHz}$, and stored in a computer for off-line analysis. $f_{\mathrm{R}}$ (bursts/min) and $\mathrm{T}_{\mathrm{i}}(\mathrm{ms})$ were calculated from the mean $\mathrm{C} 4$ burst interval and $\mathrm{C} 4$ burst width, respectively, during $2-5 \mathrm{~min}$ of recording.

\section{Drugs}

The metabolically stable adenosine $\mathrm{A}_{1}$ receptor agonist RPIA (RBI, Natick, MA, U.S.A.) was dissolved in 5\% DMSO and then further diluted in standard solution to $1.0 \mu \mathrm{M}$. The adenosine receptor antagonist theophylline (Sigma Chemical Co.) was diluted in standard solution to a final concentration of $20 \mathrm{mg} / \mathrm{L}$ from a $1 \mathrm{mM}$ stock solution in ethanol. The final concentrations of DMSO or ethanol in the solutions were $<0.01 \%$, and control experiments with only DMSO or ethanol added to the standard solution did not change the respiratory activity. Drug solutions were prepared freshly to ensure full potency of drug effect. All drugs were added to the aCSF, and the $\mathrm{pH}$ was equilibrated to 7.4 with $95 \% \mathrm{O}_{2}$ and $5 \% \mathrm{CO}_{2}$ before application to the preparation, which was started by switching perfusion from normal to drug-containing aCSF. Sufficient time to reach steady-state drug response (R-PIA, 20 $\mathrm{min}$, and theophylline, $15 \mathrm{~min}$ ), as previously determined (5, 9 ), was allowed before evaluation of drug effect was performed.

\section{Receptor Autoradiography and In Situ Hybridization}

Rat brains were examined at E14, E18, E21, exactly $2 \mathrm{~h}$ and $24 \mathrm{~h}$ after vaginal delivery, and P3, P7, and P14. From each treatment group six animals (from two litters) were used for in situ hybridization and receptor binding studies. From embryos and pups until P3 the whole head was frozen whereas in older animals the brain was rapidly dissected out. Heads and brain were then frozen on dry ice and stored at $-20^{\circ} \mathrm{C}$. Sagittal sections from the left hemisphere were cut using a Leitz cryostat. Sections were collected from the lateral part of the 
olfactory bulb toward the midline. For in situ hybridization, $14-\mu \mathrm{m}$-thick sections were thaw-mounted on poly-L-lysine (50 $\mu \mathrm{g} / \mathrm{mL}$ ) -coated slides, and for autoradiography $10-\mu \mathrm{m}$-thick sections were thaw-mounted on gelatin-coated slides. Specimens from different ages were processed in the same in situ hybridization and receptor binding runs to allow comparison of signals and binding density.

Adenosine $A_{1}$-receptor autoradiography. Receptor density was determined using receptor autoradiography with the adenosine $\mathrm{A}_{1}$ receptor antagonist $\left[{ }^{3} \mathrm{H}\right] \mathrm{DPCPX}(0.5 \mathrm{nM})$, and nonspecific binding was determined using R-PIA $(100 \mu \mathrm{M})$. Tenmicrometer sections were preincubated in $170 \mathrm{mM}$ Tris- $\mathrm{HCl}$ buffer containing $1 \mathrm{mM}$ EDTA, $2 \mathrm{U} / \mathrm{mL}$ adenosine deaminase, and $1 \mathrm{mM} \mathrm{MgCl}{ }_{2}$ at $37^{\circ} \mathrm{C}$ for $30 \mathrm{~min}$. Sections were then washed twice for $10 \mathrm{~min}$ at $23^{\circ} \mathrm{C}$ in $170 \mathrm{mM}$ Tris- $\mathrm{HCl}$ buffer. Incubations were performed for $2 \mathrm{~h}$ at $23^{\circ} \mathrm{C}$ in $170 \mathrm{mM}$ Tris- $\mathrm{HCl}$ buffer containing $\left[{ }^{3} \mathrm{H}\right] \mathrm{DPCPX}(120 \mathrm{Ci} / \mathrm{mmol}, 0.5$ $\mathrm{nM}), 2 \mathrm{U} / \mathrm{mL}$ adenosine deaminase, and $100 \mu \mathrm{M}$ GTP. The incubation with DPCPX was performed in the presence of GTP to convert all of the receptors to the low-affinity state for agonists and thereby remove all endogenous adenosine (24). Sections were then washed twice for 5 min each in ice-cold Tris-HCl, dipped three times in ice-cold distilled water, and dried at $4{ }^{\circ} \mathrm{C}$ using a strong fan. Slides were exposed to ${ }^{3} \mathrm{H}$ film (Amersham Pharmacia Biotech, Uppsala, Sweden) with ${ }^{3} \mathrm{H}$ microscales for $4 \mathrm{wk}$.

Adenosine $A_{1}$ receptor agonist-stimulated $\left.G T P \gamma P^{35} S\right]$ autoradiography. G-protein coupling of adenosine $\mathrm{A}_{1}$ receptors during development was determined using GTP $\gamma\left[{ }^{35} \mathrm{~S}\right]$ autoradiography (25) with the adenosine $\mathrm{A}_{1}$ receptor agonist CPA $(30 \mathrm{nM})$. Ten-micrometer-thick sections mounted on gelatincoated slides were incubated in $50 \mathrm{mM}$ Tris- $\mathrm{HCl}$ buffer $(\mathrm{pH}$ 7.7) containing $3 \mathrm{mM} \mathrm{MgCl}_{2}, 0.2 \mathrm{mM}$ EGTA, and $100 \mathrm{mM}$ $\mathrm{NaCl}$ at $25^{\circ} \mathrm{C}$ for $10 \mathrm{~min}$. Slides were then incubated in Tris- $\mathrm{HCl}$ buffer containing GDP $(1 \mathrm{mM})$ at $25^{\circ} \mathrm{C}$ for $25 \mathrm{~min}$. Incubations were performed for $2 \mathrm{~h}$ at $25^{\circ} \mathrm{C}$ in $50 \mathrm{mM}$ Tris- $\mathrm{HCl}$ buffer containing GTP $\gamma\left[{ }^{35} \mathrm{~S}\right](1250 \mathrm{Ci} / \mathrm{mmol}$, purchased from PerkinElmer Life Science Products, Boston, MA, U.S.A., 0.04 $\mathrm{nM})$, GDP $(30 \mathrm{mM})$, and (CPA, $30 \mathrm{mM})$. The basal activity was assessed with GDP in the absence of $\mathrm{A}_{1}$ receptor agonist, and nonspecific binding was assessed in the presence of the GTP analog Gpp(NH)p (100 $\mu \mathrm{M})$. Sections were then washed twice for $10 \mathrm{~min}$ each in ice-cold Tris-HCl, dipped three times in ice-cold distilled water, and dried at $4^{\circ} \mathrm{C}$ using a strong fan. Slides were exposed to Hyperfilm $\beta$-max (Amersham, Pharmacia Biotech, Uppsala, Sweden) for $24 \mathrm{~h}$.

In situ hybridization. The mRNA for the $\mathrm{A}_{1}$ receptor was identified with an antisense oligonucleotide probe. The 48-mer $\mathrm{A}_{1}$ adenosine receptor probe was complementary to nucleotides $985-1032$ of the rat $A_{1}$ receptor (26). The probe has been tested for specificity (27). The oligodeoxyribonucleotides were radiolabeled using terminal deoxyribonucleotidyl transferase and ${ }^{35} \mathrm{~S}$-dATP to a specific activity of about $10^{9} \mathrm{cpm} / \mu \mathrm{g}$. Slide-mounted sections were hybridized in a cocktail containing $50 \%$ formamide, $4 \times$ saline-sodium citrate, $1 \times$ Denhardt's solution, $1 \%$ sarcosyl, $0.02 \mathrm{M} \mathrm{NaPO}_{4}(\mathrm{pH} 7.0), 10 \%$ dextran sulfate, $0.06 \mathrm{M}$ dithiothreitol, $0.5 \mathrm{mg} / \mathrm{mL}$ sheared salmon sperm DNA, and $10^{7} \mathrm{cpm} / \mathrm{mL}$ of probe. After hybridization for
$15 \mathrm{~h}$ at $42^{\circ} \mathrm{C}$, the sections were washed four times in $1 \times$ saline-sodium citrate at $55^{\circ} \mathrm{C}$, then dipped briefly in water, $70 \%, 95 \%$, and $99.5 \%$ ethanol, and air-dried. Finally, the sections were apposed to Hyperfilm $\beta$-max for 4 wk.

Image analysis. Analysis of receptor expression and binding was performed using a computerized image-analysis system (Imaging Systems, St. Catherines, Ontario, Canada). Relative OD of expression or binding was measured in autoradiographs, and amounts of receptor-bound radioactivity of the specific brain regions were determined using ${ }^{3} \mathrm{H}$ microscale standards (Amersham Pharmacia Biotech). Specific binding was calculated by subtraction of the OD values in sections in which nonspecific binding was determined. Different regions of the brain in the prenatal rats were identified using the atlas by Altman and Bayer (28) and in postnatal rats using atlases by Sherwood and Timiras (29) and Paxinos et al. (30).

\section{Statistical Analysis}

Off-line analysis was performed using a personal computer and the commercially available programs Axoscope and Axotape (Axon Inc., Foster, CA, U.S.A.), Origin (Microcal Software Inc., Northampton, MA, U.S.A.), and JMP (SAS Institute Inc., Cary, NC, U.S.A.). The results are presented as mean \pm SEM. After ANOVA by the $F$ test, statistical analysis was performed by multivariate analysis of variance (MANOVA) repeated-measure design, two-tailed paired $t$ test, or Wilcoxon signed rank test when variance was unequal. Tukey-Kramer's HSD test was used to compare multiple means. Spearman rank nonparametric correlation was performed on variables with respect to postnatal age, to evaluate a possible age-dependency of the results. Quantitative receptor autoradiography and in situ hybridization results were analyzed by MANOVA using the procedures in the SYSTAT program (HALLOGRAM Publishing, Aurora, CO, U.S.A.). All these measurements were performed on sections from six animals. A $p \leq 0.05$ was considered to be statistically significant.

\section{RESULTS}

Development of brain stem respiratory rhythm. An irregular rhythmic respiratory activity was established in all preparations at $\mathrm{E} 18$ (Fig. $1 A$ ). The $f_{\mathrm{R}}$ at E18 was slower than at all other ages $(p<0.05$, Tukey-Kramer's HSD test) The regularity of respiratory activity, measured as a decrease in the $\mathrm{CV}$ of the interval between $\mathrm{C} 4$ burst discharges, increased with embryonic and postnatal age $(p<0.0001$, age versus CV Spearman rank correlation; Fig. $1 B$ ). $\mathrm{T}_{\mathrm{i}}$ in each $\mathrm{C} 4$ burst increased with embryonic age (E18, $414 \pm 90 \mathrm{~ms}$; E21, $641 \pm 135 \mathrm{~ms}$; P2h, $819 \pm 81 \mathrm{~ms}$; P24h, $860 \pm 57 \mathrm{~ms}$; P72h, $812 \pm 91 \mathrm{~ms}$; $p<0.05$, ANOVA). At E21 a respiratory pattern resembling that after birth had been established with regard to pontine inhibition, control $f_{\mathrm{R}}$, and $\mathrm{T}_{\mathrm{i}}$. When comparing the central respiratory rhythm generated before birth (E21) with that generated 2 and $24 \mathrm{~h}$ after birth, no significant differences were found.

In preparations in which recordings initially were performed with the pons remaining ( $n=44$, E18-P3), removal of the pons resulted in a significant increase in $f_{\mathrm{R}}$ (from $2.3 \pm 0.3$ to 
A

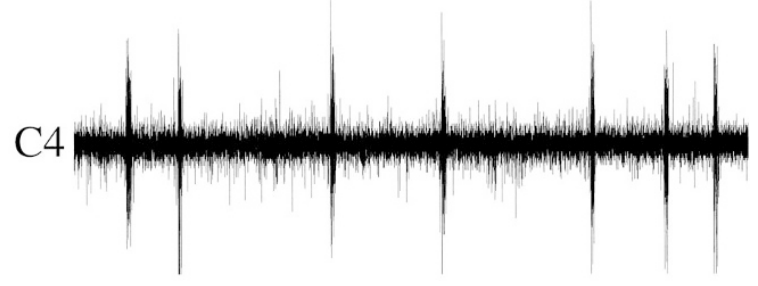

B

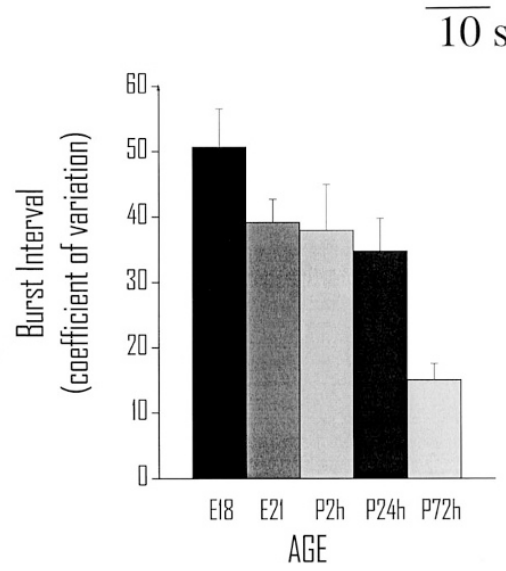

Figure 1. Development of brain stem respiratory rhythm generation. A, continuous but irregular $\mathrm{C} 4$ respiratory frequency and burst width from a fetal (E18) brain stem-spinal cord preparation without the pons. $B$, regularity of respiratory rhythm quantified as $\mathrm{CV}$ of $\mathrm{C} 4$ burst interval (mean $\pm \mathrm{SEM}$ ). Regularity of rhythmic respiratory activity increased with postnatal age (age $v s$ $\mathrm{CV}$, Spearman rank correlation $p<0.0001$ ).

$9.1 \pm 0.3$ bursts $/$ min; $p<0.0001$, paired $t$ test; Fig. $2 A$ ). Mean $f_{\mathrm{R}}$ did not differ between age groups when the pons remained (Fig. 2B, top), but was significantly slower at E18 after pontomedullary transection compared with all other age groups ( $p$ $<0.01$, Tukey-Kramer's HSD test; Fig. 2B, middle).

Effect of R-PIA on medullary respiratory rhythm. In the experiments in which brain stem respiratory-related neuronal activity was measured, it decreased after administration of R-PIA $(1 \mu \mathrm{M})$ in parallel with $\mathrm{C} 4$ activity, as evident in Figures 3 and 4 . These depressant effects on respiratory activity were reversed by theophylline $(55 \mu \mathrm{M})$. The effect of R-PIA was age-dependent $(p<0.0001$, MANOVA, repeatedmeasures design) with less $f_{\mathrm{R}}$ reduction with increasing fetal and postnatal age. The effect of R-PIA was significantly reduced $24 \mathrm{~h}$ after birth compared with E21 and $2 \mathrm{~h}(p<0.01$, Tukey-Kramer's HSD test).

Caffeine exposure and development of respiratory rhythm. Caffeine-exposed pups did not differ from controls with respect to litter size or weight. The pontine inhibition of brain stemgenerated $\mathrm{C} 4$ activity was more pronounced in the caffeine group $(p<0.05$, MANOVA, repeated-measures design; Fig. $2 B$ ). With the pons removed, brain stem-spinal cord preparations from caffeine-exposed pups had a higher $f_{\mathrm{R}}$ than controls $(p<0.05 t$ test; Fig. 2B, middle). There was no significant difference in the response to R-PIA between preparations from caffeine-treated and control groups (Fig. 4B).

$A_{1}$ mRNA, DPCPX-binding, and $A_{1}$-stimulated $\left.G T P \gamma P^{35} S\right]$ binding. Adenosine $\mathrm{A}_{1}$ receptor mRNA was present on E14 in
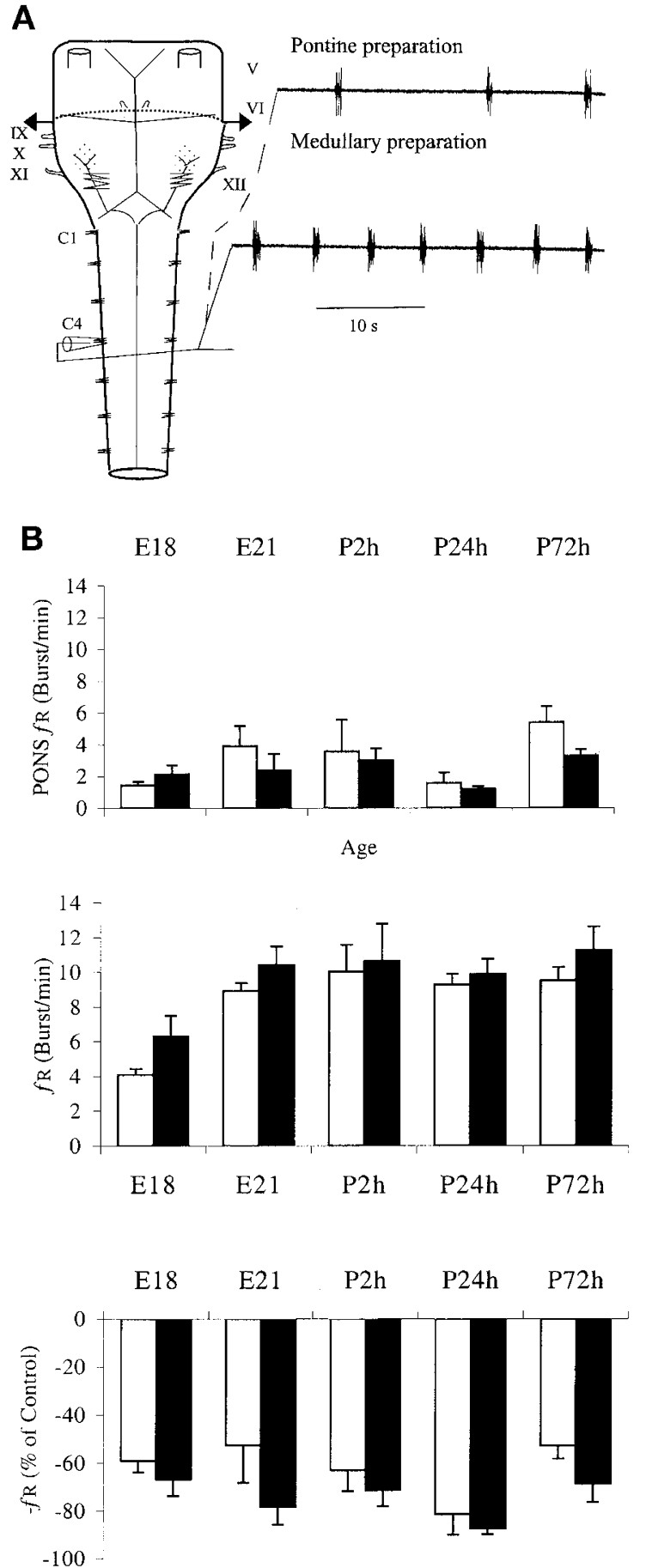

$\mathrm{AGE}$

Figure 2. Development of respiratory rhythm generation and its modulation by pons. $A$, schematic illustration of the brain stem-spinal cord preparation is shown on the left side. Dashed line indicates division when removing the pons. Cranial nerves V-XII and ventral roots $\mathrm{C} 1-\mathrm{C} 4$ are shown. On the right side the respiratory activity in a preparation from a 1-d-old postnatal rat before (upper trace) and after removal of the pons (lower trace). $B$, mean \pm SEM control C4 $f_{\mathrm{R}}$ (bursts/min) in brain stem-spinal cord preparation with pons (top) and with pons removed (middle), and inhibition exerted by pons on respiratory rhythm generated in medulla oblongata (bottom, $\%$ of control $f_{\mathrm{R}}$ with pons intact compared with $f_{\mathrm{R}}$ after removal of pons) plotted against age. Both pontine inhibition of respiratory activity and basal $f_{\mathrm{R}}$ were increased in the caffeinetreated group ( $p<0.05$, MANOVA, repeated-measures design). White columns represent control group $(n=5-8)$ and black columns represent caffeinetreated group $(n=4-6)$. 

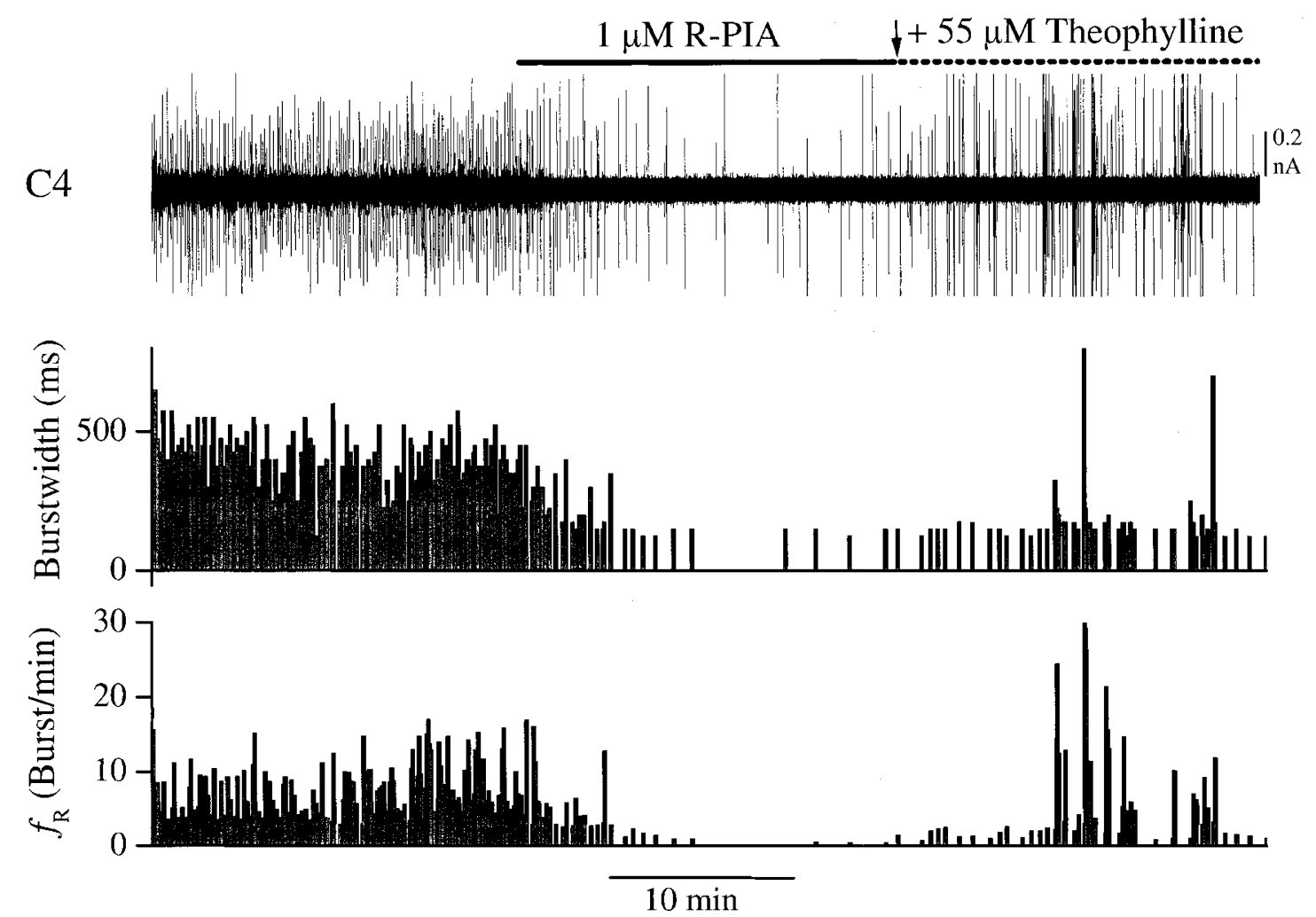

Figure 3. Effects of R-PIA on fetal respiratory activity. Tracings depict respiratory activity recorded from E18 preparation. Note that the effect of R-PIA is pronounced and reversible by theophylline. Upper trace, $\mathrm{C} 4$ respiratory activity; middle trace, burst width $\left(\mathrm{T}_{\mathrm{i}}\right)$ in ms; and lower trace, $f_{\mathrm{R}}$ (bursts/min).

low levels in the pontine neuroepithelium. On E21, specific $\mathrm{A}_{1}$ mRNA expression was identified in the pontine gray nucleus (not shown). In pups decapitated shortly after vaginal delivery ( 2 and $24 \mathrm{~h}$ ), there were no dramatic changes in adenosine receptors in the brain compared with levels just before birth, but at P3 there was a tendency to a down-regulation of $\mathrm{A}_{1}$ mRNA expression. At P7 $\mathrm{A}_{1}$ mRNA was selectively expressed and DPCPX-binding was enriched in several brain stem nuclei, including the pontine gray nucleus (Fig. 5A). The facial nucleus, lateral reticular nucleus, and the periambiguous area also seemed to have increased binding.

When adenosine $\mathrm{A}_{1}$ receptors were stimulated with CPA, basal GTP $\gamma\left[{ }^{35} \mathrm{~S}\right]$ binding in the pons and medulla was more than doubled at E18, E21, and P24h ( $p<0.001$, two-way ANOVA), indicating a functional coupling to G-proteins of these receptors already at E18 (Fig. 6). Caffeine-exposed animals had the same levels of $\mathrm{A}_{1}$ mRNA in the pons and medulla as controls, but $\left[{ }^{3} \mathrm{H}\right] \mathrm{DPCPX}$ binding was slightly higher in the caffeine-treated animals than in controls; however, data were only significant when pooled from different age groups. There was an increased $\left[{ }^{3} \mathrm{H}\right] \mathrm{DPCPX}$ binding in the pons when comparing E18-P7 $(2-47 \%, p=0.019)$ and in the medulla when comparing $\mathrm{P} 24 \mathrm{~h}-\mathrm{P} 14(12-37 \%, p=0.018)$.

\section{DISCUSSION}

The present study shows that whereas there seems to be no dramatic change of basic respiratory rhythm control at birth, an adenosine $A_{1}$ receptor agonist inhibits the respiratory rhythm generation more markedly before and around birth than $24 \mathrm{~h}$ postnatally. Furthermore, in pups chronically exposed to a low dose of caffeine via maternal intake, the pontine inhibition of brain stem respiratory rhythm is more pronounced compared with that of controls.

Perinatal development of respiratory rhythm. We demonstrate that even though the isolated CPG for breathing continuously matures during perinatal life, no major change in pontine inhibition, $f_{\mathrm{R}}, \mathrm{T}_{\mathrm{I}}$, or stability of pattern occurs between E21 and 2 and $24 \mathrm{~h}$ after birth. These findings indicate that it is mainly afferent, suprapontine input and changes in the local environment (i.e. increased $\mathrm{PO}_{2}$ ) that alter breathing from a discontinuous to a continuous behavior at birth.

We also show that the pontine inhibition of respiratory centers in the medulla is already present at E18 and does not change between E21 and P3. This inhibition is mediated by noradrenergic activity originating from A5 pontine structures (19). The A5 nucleus appears in the rat on fetal day 17 (31) and our new findings suggest that already at E18, the A5 nucleus modulates medullary respiratory activity. Thus, the pons may be involved in the formation of the early CPG for respiration. This would be in accordance with previous data demonstrating an important role of the pons in the development of medullary respiratory networks and control of breathing (32). We could not demonstrate a change in the pontine inhibition around birth. However, our studies were performed using similar in vitro conditions for preparations taken before and after birth. A postnatal change in $\mathrm{PO}_{2}$ would probably decrease the activity of the A5 nucleus in vivo, causing less pontine inhibition and thus increasing CPG activity in the medulla oblongata after birth. 

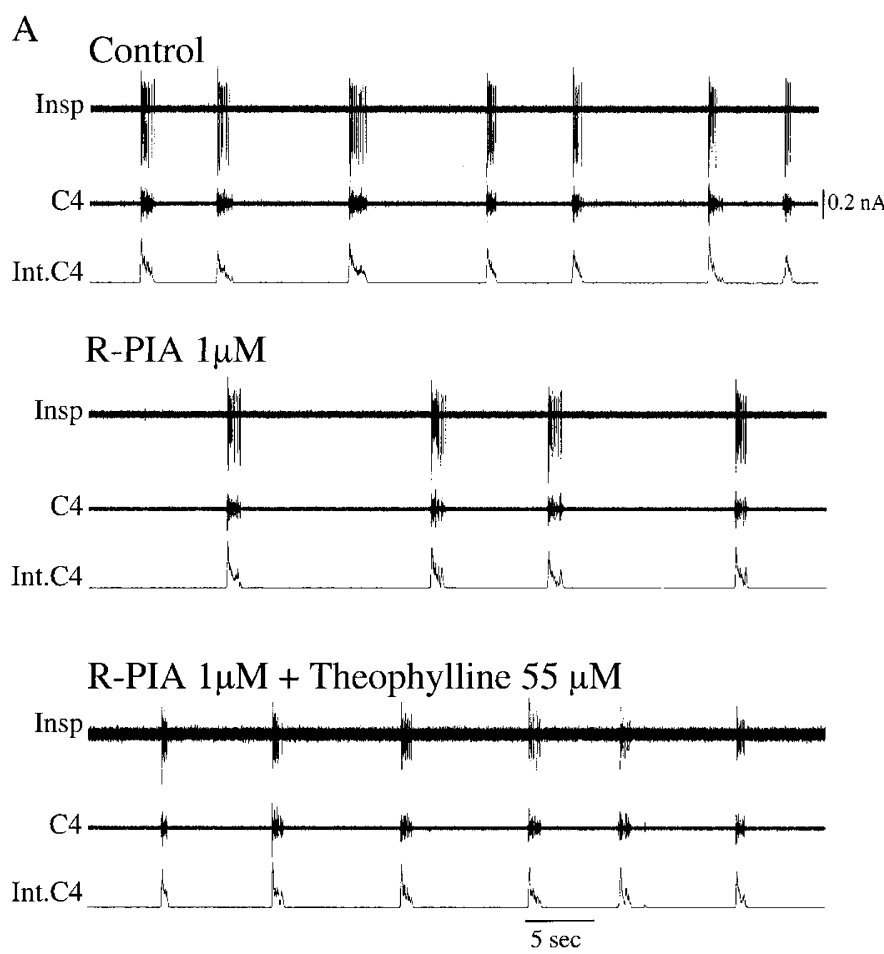

B

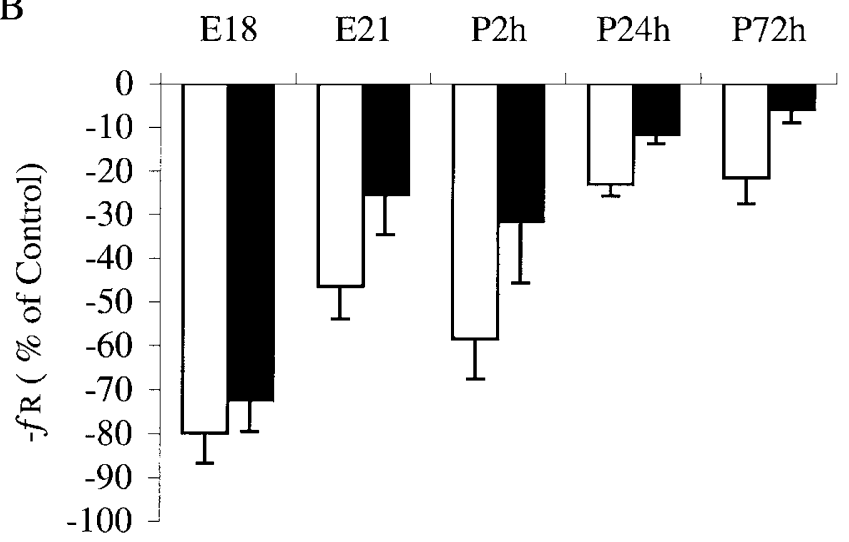

AGE

Figure 4. Age-related effects of R-PIA on respiratory activity. $A$, recording from E21 rat and effects of R-PIA $(1 \mu \mathrm{M})$ and theophylline $(55 \mu \mathrm{M})$. Insp, inspiratory neuron; $C 4, \mathrm{C} 4$ ventral root activity; Int.C4, integrated C4. $B$, mean \pm SEM response ( $\%$ of control) of $\mathrm{C} 4 f_{\mathrm{R}}$ to R-PIA plotted against age. The effect of R-PIA was related to perinatal age ( $p<0.0001$, MANOVA, repeatedmeasures design). Within $24 \mathrm{~h}$ after birth the respiratory depressant effect of R-PIA is decreased $(p<0.05)$ compared with the effect at E21 and P2 h. No significant difference in the response to R-PIA was found between the control (white columns) and caffeine-exposed groups (black columns).

Adenosinergic respiratory depression decrease after birth. A reduced ability of adenosine $\mathrm{A}_{1}$ agonist to decrease respiratory activity occurred already within $24 \mathrm{~h}$ postnatally (Fig. 4). This new finding narrows the window when a switch in adenosine's ability to depress breathing occurs. Previous studies in rats $(5,9)$, rabbits $(4)$, and piglets $(33)$, have reported a similar reduction of adenosinergic effect to occur within the first days or weeks after birth. Immediately after birth, as the partial pressure for oxygen increases, circulating levels of adenosine decrease $(3,34)$, correlating with decreased extracellular levels in the brain (10), and thus the adenosinergic inhibition of breathing is reduced. Taken together with the present findings, this will contribute to an increased activity of the CPG and establishment of continuous breathing. The changes in $f_{\mathrm{R}}$ were accompanied by a simultaneous change in brain stem respiration-related neuronal activity in all preparations in which recordings were performed. This suggests that adenosine also during the fetal period affects $f_{\mathrm{R}}$ by acting on brain stem respiratory neurons via adenosine $A_{1}$ receptors in the medulla oblongata (9).

Caffeine exposure and development of respiratory rhythm. Here we demonstrate that long-term caffeine intake during gestation and the early postnatal period increases the baseline frequency of $\mathrm{C} 4$ respiratory output. Adenosine depresses and adenosine antagonist increases respiration during control conditions $(5,35)$, suggesting the occurrence of an endogenous adenosinergic tonic activity during the perinatal period. In addition, long-term caffeine intake seems to increase the inhibition exerted by pontine structures in vitro. Methylxanthines increase the turnover of noradrenaline (36) and spontaneous electrical activity of noradrenergic neurons. Thus a possible explanation for our findings could be that caffeine, by inducing an increased activity of pontine noradrenergic neurons such as those situated in the A5 area, increases the inhibition from pontine structures to the respiratory centers in the medulla oblongata. This finding is of interest because the pons is involved in respiratory depression during hypoxia (18). We have preliminary in vivo data indicating a change in hypoxic respiratory response in caffeine-treated pups, which could agree with the present in vitro findings of a change in pontine control of brain stem activity. However, further studies will be needed to elucidate eventual detrimental effects on respiratory control in vivo.

$A_{1} m R N A, D P C P X$-binding, and $A_{1}$-stimulated GTP $\left.\left.\gamma\right|^{35} S\right]$ binding. A new finding is that $\mathrm{A}_{1}$ receptor coupling to $\mathrm{G}$ protein occurred prenatally in the brain stem as indicated by $\mathrm{A}_{1}$-stimulated GTP $\gamma\left[{ }^{35} \mathrm{~S}\right]$ binding (Fig. 6). This is in contrast to previous studies indicating that the major development in terms of density and coupling to second messenger-forming systems in the cerebral cortex and hippocampus occurs postnatally $(37,38)$. However, the phylogenetically old brain stem matures earlier than the phylogenetically younger parts of the brain examined in the previous studies. Thus, $\mathrm{A}_{1}$-receptor coupling to G-proteins occurs prenatally in the brain stem. We found robust $\mathrm{A}_{1}$ mRNA labeling and DPCPX binding in the pons-medulla toward the end of gestation (E18-E21) and thereafter in accordance with previous studies $(39-41)$. The pontine gray nucleus is connected to cerebellum, and we are not aware of reports indicating a relation to respiratory control. Our finding of increased binding in brain stem nuclei, including the periambiguous area, agrees with a previous study in immature sheep (42), which reported that the highest density of $A_{1}$ receptors are found in the rostral ventrolateral medulla, the area that contains the CPG for respiration (43). However, in the present study receptor binding was examined in sagittal slices, and a more precise determination of adenosine $\mathrm{A}_{1}$ mRNA and $A_{1}$ receptor distribution within the brain stem was not per- 
A
Receptor-binding

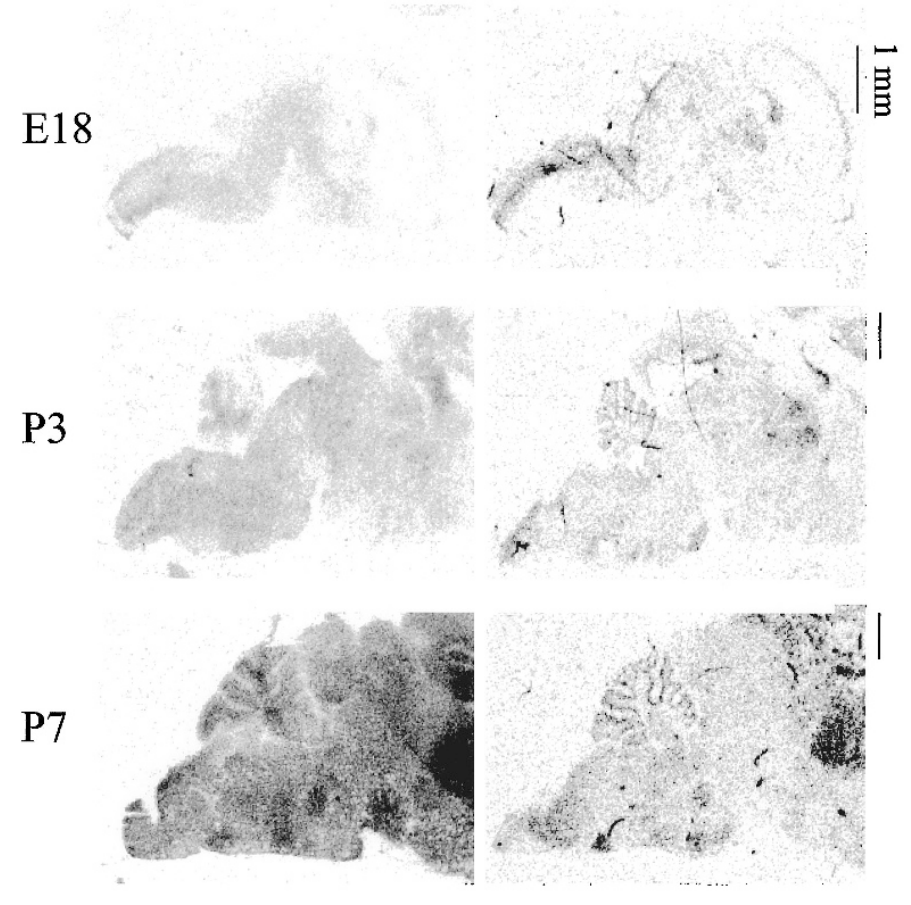

$\mathrm{A}_{1}$-mRNA

要
B

Pons

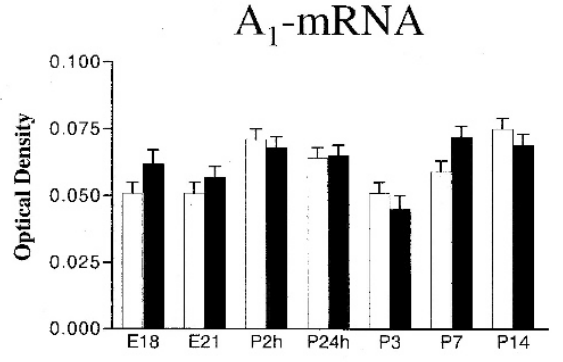

$\mathrm{A}_{1}$-receptors

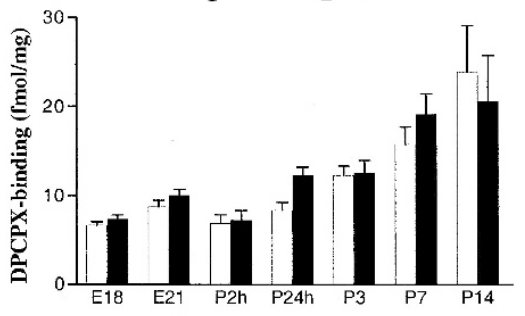

C

\section{Medulla \\ Oblongata}

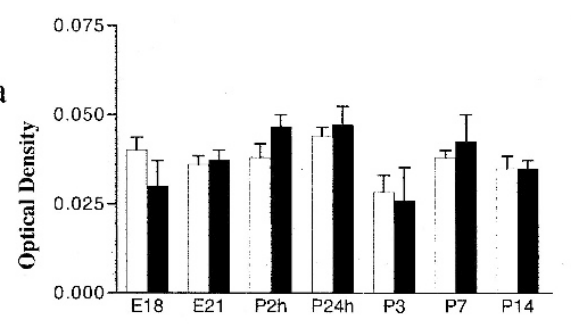



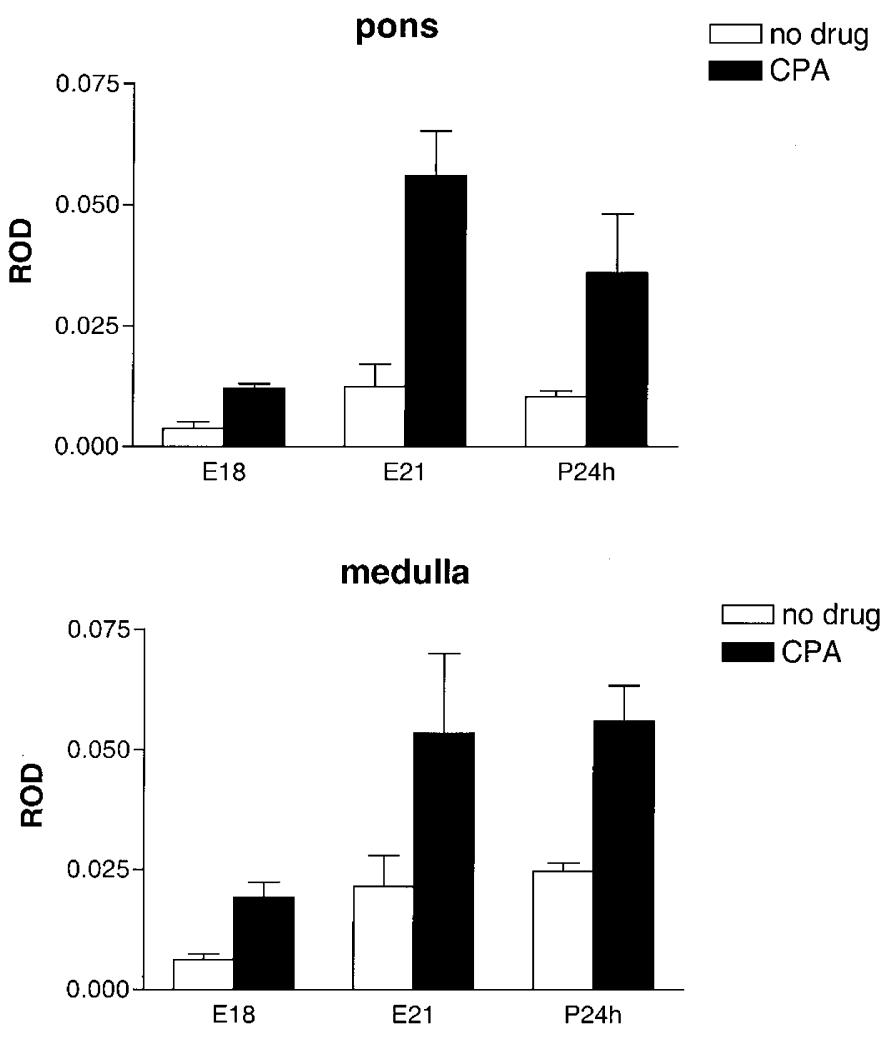

Figure 6. $A_{1}$ receptors and functional G-protein coupling. Basal GTP $\gamma\left[{ }^{35} \mathrm{~S}\right]$ binding (white bars) and GTP $\gamma\left[{ }^{35} \mathrm{~S}\right]$ binding after stimulation with the adenosine $\mathrm{A}_{1}$ receptor agonist CPA (black bars) at E18, E21, and P24h. The increased GTP $\gamma\left[{ }^{35} \mathrm{~S}\right]$ binding after agonist stimulation indicates a functional coupling of the receptor to the G-protein already at E18 in pons (top) and medulla oblongata (bottom). Nonspecific binding was determined and was equal to background. $R O D$, relative optical density. Mean \pm SEM of groups with $n=6$.

decreased R-PIA effect in the caffeine group. Alternatively, caffeine affects $A_{1}$ receptor signaling downstream of the receptor or induces other types of adaptive changes, as occur in the adult animal in which agonist binding has been shown to increase without detectable changes in $\mathrm{A}_{1} \mathrm{mRNA}$ or antagonist binding $(45,46)$.

The effect of the adenosine $A_{1}$ receptor agonist R-PIA decreased within $24 \mathrm{~h}$ after birth. However, there was no corresponding decrease in $A_{1}$ receptor binding or $A_{1}$ stimulated G-protein coupling $24 \mathrm{~h}$ after birth. A decreased binding affinity of $A_{1}$ receptor to $A_{1}$ agonist has previously been reported to occur with increasing postnatal age $(4,47)$. This could explain the decreased sensitivity for adenosine $A_{1}$ receptor-mediated respiratory depression after birth; however, this was not determined in the present study.

We conclude that respiration is already strongly modulated by adenosinergic action at the level of the medulla oblongata at E18 and that this modulatory action is reduced $24 \mathrm{~h}$ after birth. Furthermore, long-term maternal caffeine intake during gestation increases the pontine inhibition of and the activity of medulla oblongata respiratory centers in offspring without changing $A_{1}$ receptor mRNA and protein expression.
Acknowledgments. The authors thank Dr. Michael Runold and Prof. Bertil Fredholm for valuable comments on the manuscript and Assoc. Prof. R.A. Harris for English corrections.

\section{REFERENCES}

1. Maloney JE, Adamson TM, Brodecky V, Dowling MH, Ritchie BC 1975 Modification of respiratory center output in the unanesthetized fetal sheep "in utero." J Appl Physiol 39:552-558

2. Blanco C 1991 Role of the brainstem in the changes at birth; initiation of continuous breathing and its maintenance. In: Hanson MA (ed) The Fetal and Neonatal Brainstem: Developmental and Clinical Issues. University Press, Cambridge, pp 106-126

3. Irestedt L, Dahlin I, Hertzberg T, Sollevi A, Lagercrantz H 1989 Adenosine concentration in umbilical cord blood of newborn infants after vaginal delivery and cesarean section. Pediatr Res 26:106-108

4. Runold M, Lagercrantz H, Fredholm BB 1986 Ventilatory effect of an adenosine analogue in unanesthetized rabbits during development. J Appl Physiol 61:255-259

5. Herlenius E, Lagercrantz H, Yamamoto Y 1997 Adenosine modulates inspiratory neurons and the respiratory pattern in the brainstem of neonatal rats. Pediatr Res $42: 46-53$

6. Lagercrantz H, Yamamoto Y, Fredholm BB, Prabhakar NR, Euler C 1984 Adenosine analogues depress ventilation in rabbit neonates: theophylline stimulation of respiration via adenosine receptors? Pediatr Res 18:387-390

7. Barraco RA, el Ridi MR, Parizon M 1990 The adenosine analog, 5'- $N$ ethylcarboxamidoadenosine, exerts mixed agonist action on cardiorespiratory parameters in the intact but not decerebrate rat following microinjections into the nucleus tractus solitarius. Brain Res 530:54-72

8. Bissonnette JM, Hohimer AR, Knopp SJ 1991 The effect of centrally administered adenosine on fetal breathing movements. Respir Physiol 84:273-285

9. Herlenius E, Lagercrantz H 1999 Adenosinergic modulation of respiratory neurones in the neonatal rat brainstem in vitro. J Physiol 518:159-172

10. Koos BJ, Mason BA, Punla O, Adinolfi AM 1994 Hypoxic inhibition of breathing in fetal sheep: relationship to brain adenosine concentrations. J Appl Physiol 77:27342739

11. Fredholm BB, Battig K, Holmen J, Nehlig A, Zvartau EE 1999 Actions of caffeine in the brain with special reference to factors that contribute to its widespread use. Pharmacol Rev 51:83-133

12. Guillet R, Kellogg CK 1991 Neonatal exposure to therapeutic caffeine alters the ontogeny of adenosine A, receptor in brain of rats. Neuropharmacol 30:489-496

13. Guillet R 1990 Neonatal caffeine exposure alters adenosine receptor control of locomotor activity in the developing rat. Dev Pharmacol Ther 15:94-100

14. Tye K, Pollard I, Karlsson L, Scheibner V, Tye G 1993 Caffeine exposure in utero increases the incidence of apnea in adult rats. Reprod Toxicol 7:449-452

15. Guillet R, Dunham L 1995 Neonatal caffeine exposure and seizure susceptibility in adult rats. Epilepsia 36:743-749

16. Holloway WRJ, Thor DH 1982 Caffeine sensitivity in the neonatal rat. Neurobehav Toxicol Teratol 4:331-333

17. Yoneyama Y, Shin S, Iwasaki T, Power GG, Araki T 1994 Relationship between plasma adenosine concentration and breathing movements in growth-retarded fetuses. Am J Obstet Gynecol 171:701-706

18. Okada Y, Kawai A, Muckenhoff K, Scheid P 1998 Role of the pons in hypoxic respiratory depression in the neonatal rat. Respir Physiol 111:55-63

19. Hilaire G, Monteau R, Errchidi S 1989 Possible modulation of the medullary respiratory rhythm generator by the noradrenergic A5 area: an in vitro study in the newborn rat. Brain Res 485:325-332

20. Di Pasquale E, Monteau R, Hilaire G 1992 In vitro study of central respiratory-like activity in the fetal rat. Exp Brain Res 89:459-464

21. Greer JJ, Smith JC, Feldman JL 1992 Respiratory and locomotor patterns generated in the fetal rat brain stem-spinal cord in vitro. J Neurophysiol 67:996-999

22. Suzue T 1984 Respiratory rhythm generation in the in vitro brainstem-spinal cord preparation of the neonatal rat. J Physiol (Lond) 354:173-183

23. Arata A, Onimaru H, Homma I 1990 Respiration-related neurons in the ventral medulla of newborn rats in vitro. Brain Res Bull 24:599-604

24. Fastbom J, Fredholm B 1990 Effects of longterm theophylline treatment on adenosine $\mathrm{A}_{1}$-receptors in rat brain: autoradiographic evidence for increased receptor number and altered coupling to G-proteins. Brain Res 507:195-199

25. Sim LJ, Selley DE, Childers SR 1995 In vitro autoradiography of receptor-activated $\mathrm{G}$ proteins in rat brain by agonist-stimulated guanylyl $5^{\prime}-\left[\gamma-\left[{ }^{35} \mathrm{~S}\right]\right.$ thio $]$-triphosphate binding. Proc Natl Acad Sci USA 92:7242-7246

26. Mahan LC, McVittie LD, Smyk-Randall EM, Nakata H, Monsma Jr FJ, Gerfen CR, Sibley DR 1991 Cloning and expression of an $A_{1}$ adenosine receptor from rat brain. Mol Pharmacol 40:1-7

27. Johansson B, Ahlberg S, van der Ploeg I, Bren:e S, Lindefors N, Persson H, Fredholm BB 1993 Effect of long term caffeine treatment on $A_{1}$ and $A_{2}$ adenosine receptor binding and on mRNA levels in rat brain. Naunyn Schmiedebergs Arch Pharmacol 347:407-414

28. Altman J, Bayer SA 1995 Atlas of Prenatal Rat Brain Development. CRC Press, Boca Raton, FL, p 589

29. Sherwood SN, Timiras PS 1970 A Stereotaxic Atlas of the Developing Brain. Univ of California Press, California Press, Berkeley, CA, U.S.A.

30. Paxinos G, Törk I, Tecott LH, Valentino KL 1991 Atlas of the Developing Rat Brain. Academic Press, San Diego, p 271

31. Amaral DG, Sinnamon HM 1977 The locus coeruleus: neurobiology of a central noradrenergic nucleus. Prog Neurobiol 9:147-196 
32. Jacquin TD, Borday V, Schneider-Maunoury S, Topilko P, Ghilini G, Kato F, Charnay P, Champagnat J 1996 Reorganization of pontine rhythmogenic neuronal networks in Krox-20 knockout mice. Neuron 17:747-758

33. Elnazir B, Marshall JM, Kumar P 1996 Postnatal development of the pattern of respiratory and cardiovascular response to systemic hypoxia in the piglet: the roles of adenosine. J Physiol (Lond) 492:573-585

34. Fukuda S, Katoh S, Yamamoto K, Hashimoto M, Kitao M 1990 Correlation between levels of plasma adenosine triphosphate and stress to the fetus at delivery. Biol Neonate 57:150-154

35. Schmidt C, Bellingham MC, Richter DW 1995 Adenosinergic modulation of respiratory neurones and hypoxic responses in the anaesthetized cat. J Physiol (Lond) 483:769-781

36. Nehlig A, Daval JL, Debry G 1992 Caffeine and the central nervous system: mechanisms of action, biochemical, metabolic and psychostimulant effects. Brain Res Rev 17:139-170

37. Johansson B, Georgiev V, Fredholm BB 1997 Distribution and postnatal ontogeny of adenosine $\mathrm{A}_{2 \mathrm{~A}}$ receptors in rat brain: comparison with dopamine receptors. Neuroscience 80:1187-1207

38. Marangos PJ, Patel J, Stivers J 1982 Ontogeny of adenosine binding sites in rat forebrain and cerebellum. J Neurochem 39:267-270

39. Rivkees SA 1995 The ontogeny of cardiac and neural $A_{1}$ adenosine receptor expression in rats. Dev Brain Res 89:202-213
40. Weaver DA $1996 \mathrm{~A}_{1}$-adenosine receptor gene expression in fetal rat brain. Dev Brain Res 94:205-223

41. Reppert SM, Weaver DR, Stehle JH, Rivkees SA 1991 Molecular cloning and characterization of a rat $A_{1}$-adenosine receptor that is widely expressed in brain and spinal cord. Mol Endocrinol 5:1037-1048

42. Bissonnette JM, Reddington M 1991 Autoradiographic localization of adenosine $A_{1}$ receptors in brainstem of fetal sheep. Dev Brain Res 61:111-115

43. Rekling JC, Feldman JL 1998 Prebötzinger complex and pacemaker neuronshypothesized site and kernel for respiratory rhythm generation. Annu Rev Physiol 60:385-405

44. Åden U, Herlenius E, Tang L-Q, Fredholm B 2000 Minor effects of maternal caffeine intake on adenosine ontogeny in the rat brain. Pediatr Res 48:177-183

45. Jacobson KA, von Lubitz DK, Daly JW, Fredholm BB 1996 Adenosine receptor ligands: differences with acute versus chronic treatment. Trends Pharmacol Sci $17: 108-113$

46. Johansson B, Georgiev V, Lindstrom K, Fredholm BB $1997 \mathrm{~A}_{1}$ and $\mathrm{A}_{2 \mathrm{~A}}$ adenosine receptors and $\mathrm{A}_{1}$ mRNA in mouse brain: effect of long-term caffeine treatment. Brain Res 762:153-164

47. Guillet R, Kellogg CK 1991 Neonatal caffeine exposure alters developmental sensitivity to adenosine receptor ligands. Pharmacol Biochem Behav 40:811-817 